\title{
Failure evidences of reduced span bridges in case of extreme rainfalls The case of Livorno
}

\author{
Mario Lucio Puppio, Sara Novelli \\ University of Pisa, Italy \\ m.puppio@ing.unipi.it,ingsara.novelli@gmail.com
}

\author{
Mauro Sassu \\ University of Cagliari, Italy \\ msassu@unica.it
}

\begin{abstract}
The heavy rainfalls occurring in Italy in the last few years focused the attention on the vulnerability of the land and the related infrastructures. Critical situations involving losses of human life and deterioration or failure of relevant structures are frequent. These events were due to: (1) improper land-use; (2) aging of infrastructures, (3) insufficient maintenance and protection; (4) climate changes causing rainstorms similar to tropical events. The failure of small bridges in road networks plays a key role in this sense. The present paper aims to analyse the behaviour of small bridges during rainfalls or floods. In particular, the recent case of Livorno is analysed. The Italian territory has about 460.000 small bridges, mostly designed without the support of technical codes or a proper interaction between the hydraulic and structural aspects. A large part of them can be submerged by water flows during rainfalls and pushed by unexpected actions.

The failure scenarios allow identifying the hydraulic and structural vulnerabilities through a specific survey. A classification of small bridges on the basis of submergibility indexes is eventually proposed.
\end{abstract}

KEYWORDS. Small bridges; Structural and hydraulic assessment; Road network safety; Livorno flood.

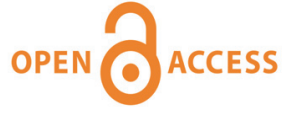

Citation: Puppio, M. L., Novelli, S., Sassu, M., Failure evidences of reduced span bridges in case of extreme rainfalls, The case of Livorno, Frattura ed Integrità Strutturale, 46 (2018) 190-202.

Received: 13.06.2018

Accepted: 16.09 .2018

Published: 01.10 .2018

Copyright: (C) 2018 This is an open access article under the terms of the CC-BY 4.0, which permits unrestricted use, distribution, and reproduction in any medium, provided the original author and source are credited.

\section{INTRODUCTION}

he recent changes in the Mediterranean climate have highlighted the vulnerability of the Italian territory to slides, floods, overflows [1, 2] and other damaging scenarios connected to meteorological variables [3-5].

Considering the mere rainfall variable a double effect can be noticed: (1) the higher annual average of precipitations and (2) the increasing occurrence of intense phenomena concentrated in small areas. Days with intense precipitations 
alternate to longer dry periods as well [5]. This scenario, quite common in tropical areas, is becoming more and more frequent even in the Mediterranean one. Its negative consequences are worsened by the improper transformation of the territory and of ecosystems, such as [6]: (1) river filling, (2) waterproofing of wide urban areas, (3) infrastructures in areas with a high hydrogeological risk, (4) inadequate secondary network of rain water discharge.

This paper deals with this last aspect, analysing the risk mitigation on reduced span bridges [7-8]. This topic involves several possible failure scenarios associated to the possibility of a hydraulic overlap of the bridge. These phenomena affect catching basins characterized by a reduced extension, which are challenged by intense and short term rains. The study case examined occurred in Livorno. During the flood in September 2017, several people were injured, while buildings, enterprises and three road bridges were damaged. The failure mechanisms will be further highlighted, emphasizing the recurring elements of vulnerability.

\section{THE LIVORNO CASE}

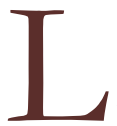

ivorno (Wgs_84: $43^{\circ} 33^{\prime} 0^{\prime \prime N}$; $10^{\circ} 19^{\prime} 0^{\prime \prime} \mathrm{E}$ ) is a town along the Tyrrhenian coast of the Italian peninsula, located on the sea. Its territory has a surface of $105 \mathrm{~km}^{2}$ with about 160.000 inhabitants. It develops lengthways along the seacoast, with a main north-southern direction. Some short watercourses, flowing from the inland to the sea towards east west, cross it (see Tab. 1).

\begin{tabular}{cccc}
\hline Number & Denomination & $\begin{array}{c}\text { Total Length* } \\
{[\mathrm{km}]}\end{array}$ & $\begin{array}{c}\text { Catching basin } \\
\text { extension* } \\
{\left[\mathrm{km}^{2}\right]}\end{array}$ \\
1 & Rio Ardenza & 7.31 & 21.20 \\
2 & Rio Cignolo & 3.96 & 0.46 \\
3 & Rio Dei Poggi & 1.13 & 0.31 \\
4 & Rio Maggiore & 9.30 & 11.29 \\
5 & Rio Paganello & 4.82 & 4.92 \\
6 & Rio Popogna & 2.31 & 4.01 \\
7 & Torrente Chioma & 9.05 & 18.68 \\
8 & Torrente Ugione & 12.17 & 11.52 \\
\hline
\end{tabular}

Table 1: river of Livorno.

The port of Livorno is one of the characterizing elements of the town (Fig. 1). It is classified as a first level port inside the Tyrrhenian Corridor [9], remarkably equipped with infrastructures and means to host fast displacement ships. Infrastructures allow the direct connection with the national road and railway networks and with the airport areas of Pisa and Florence.

Due to its significant urbanization, Livorno has several intersections between the road network and the hydrographical one (including moats and canals as well as minor watercourses). While other public works strategic for the territory (schools, hospitals, etc.) are easily identified and qualified, reduced span bridge are dealt with differently. They are widely spread on the territory (about 1 infrastructure per $\mathrm{km}$ of road development). The identification, evaluation and study of their vulnerability is discussed in [9-13].

The collapse of short span bridges is a frequent scenarios but is not so common in scientific literature as for example the failure of long span bridges [14-17].

The survey of infrastructures in this area has been carried out through Gis software (Q-GIS rel. 2.18 Las Palmas) intersecting the road network with the hydrographical one [17-18]. This instrument allows a classification of bridges according to the importance of the networks generating the intersection. In Tuscany there are about 50.000 small bridges, whose classification in the Tuscan provinces is given in Fig. 2. An average density of 2.92 intersections per $\mathrm{km}^{2}$ and a linear density of 1.06 intersections per $\mathrm{km}$ are recorded; the crossing density in the single provinces is given in Fig. 3. 


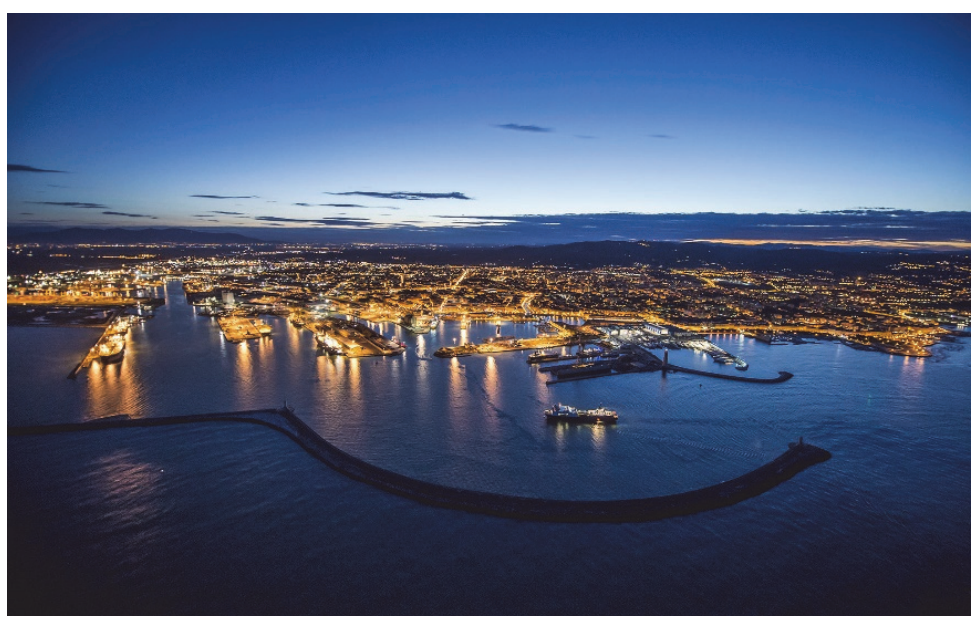

(a)

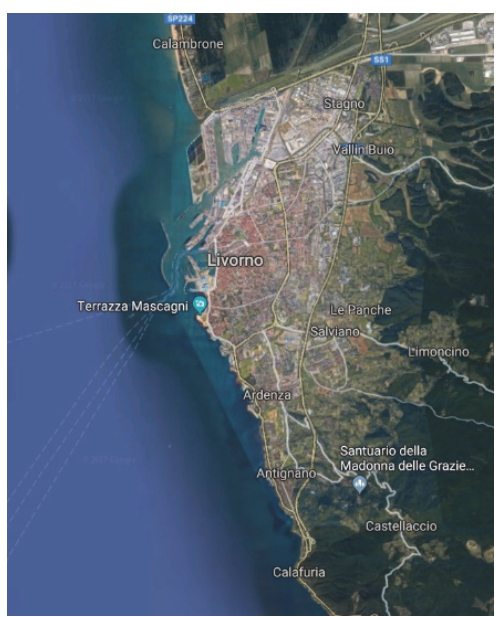

(b)

Figure 1: Livorno. Night view of the port (a); top view of the town (b).

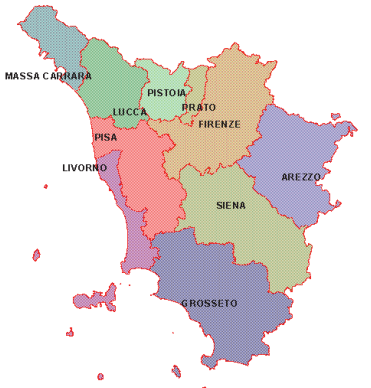

(a)

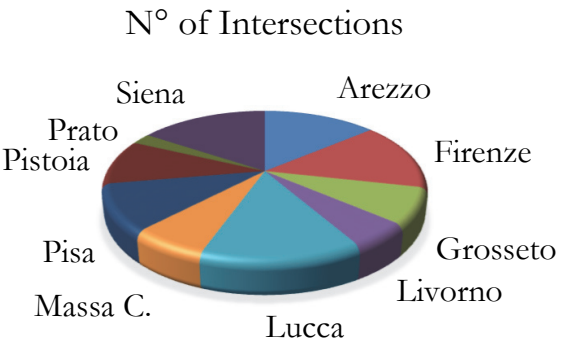

(b)

Figure 2: Distribution of small bridges in Tuscany. Extension of Tuscan provinces (a); Distribution of intersections per province (b).

Areal density of intersections

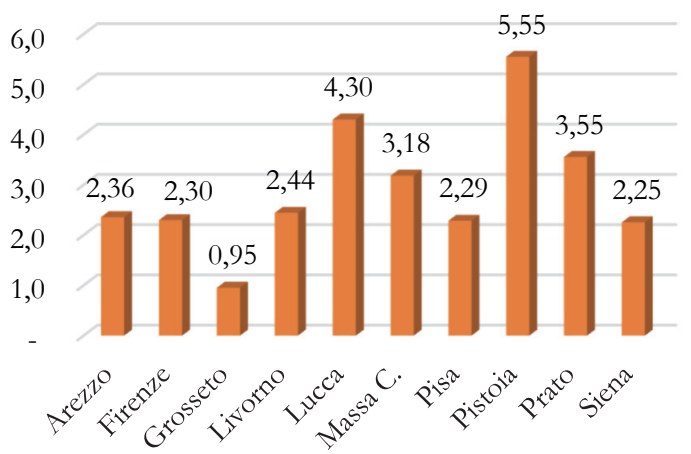

(a)
Linear density of intersections

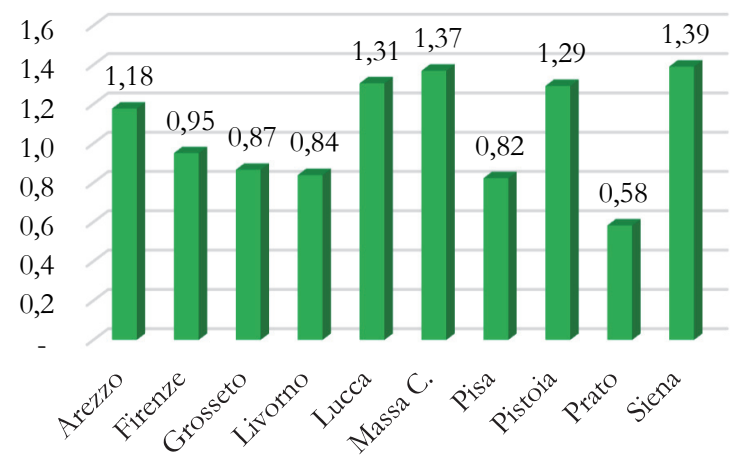

(b)

Figure 3: Areal density (a) and linear density (b) of reduced span bridges in Tuscany.

In the province of Livorno (excluding the islands) there are 2068 intersections (2965 considering also the archipelago) divided as follows: 


\begin{tabular}{ccccc}
\hline $\begin{array}{c}\text { Level of hydraulic } \\
\text { network }\end{array}$ & State & Provincial & Communal & Private \\
I & 4 & 7 & 8 & 8 \\
II & 20 & 28 & 14 & 14 \\
III & 205 & 231 & 590 & 86 \\
IV & 50 & 92 & 764 & 56 \\
\hline
\end{tabular}

Table 2: Distribution of the bridge in the province of Livorno.

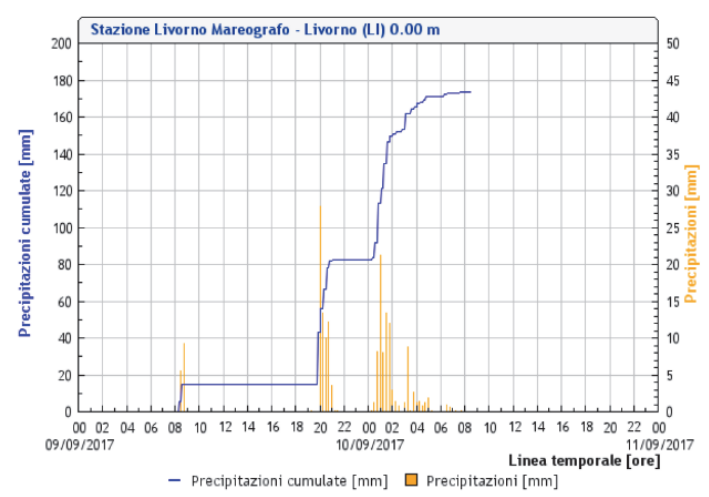

(a)

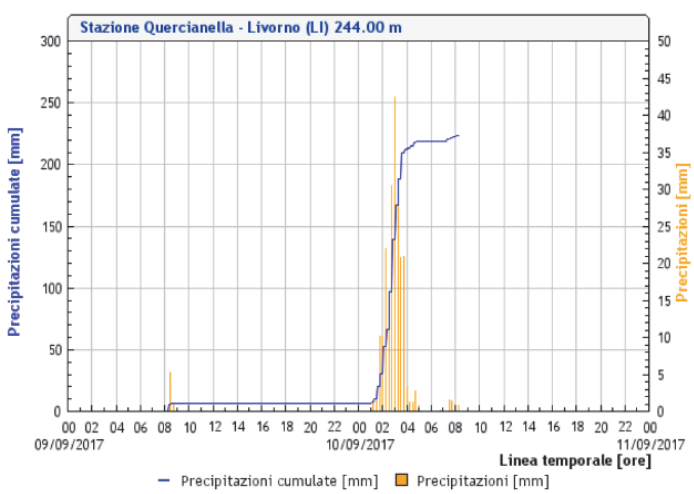

(b)

Figure 4: Rainfalls in Livorno between 09 and 10 September 2017. Station of Livorno - Mareograph, elevation 0.00m (a); Station of Quercianella, elevation $244.00 \mathrm{~m}$ (b).

\section{RAINFALLS TECHNICAL DATA}

$\mathrm{T}$ he event of Livorno in 2017 was characterised by several storm systems generated between the sea and the coast from 8 p.m. on Saturday 9 September and 6 a.m. on Sunday 10 September. The epicentre of low-pressure occurred in the area between Livorno and Pisa, with three intervals of a higher intensity (Fig. 4). During the first interval, lasting about 45 minutes, very high intensities of $24 \mathrm{~mm}$ were recorded as well as an amass of $65 \mathrm{~mm}$. Later, in the early Sunday morning of 10 September, a new stormy impulse affected mostly the areas between the south of Livorno and Rosignano. During this interval there were 65 further $\mathrm{mm}$ falling on Livorno in about two hours. This was followed by another interval with a total height of rain of about $15 \mathrm{~mm}$ in a span of 5 hours. In the province of Livorno, near the thunder centre, maximum intensities of $42.5 \mathrm{~mm}$ were recorded in 15 minutes, with $235 \mathrm{~mm}$ in 3 hours (Pluviometer of Valle Benedetta). Comparing data shows that from 18.11.2017 to 18.12.2017 about $81 \mathrm{~mm}$ of accumulated rain fell on Livorno (in 30 days) with the maximum intensity of $32.1 \mathrm{~mm}$ a day. These data highlight the exceptional characteristics of the described meteorological event. Fig. 5 shows the map of accumulated rainfalls between 0.00 and 12 p.m. on 11.09.2017 (Fig. 5 - a) and accumulated rainfalls in the Station of Bocca d'Arno (Fig. 5 - b).

For the generic weather station, the value of accumulated rain is expressed with the following relation [18]:

$$
h=a t^{n} T_{r}^{m}
$$

where:

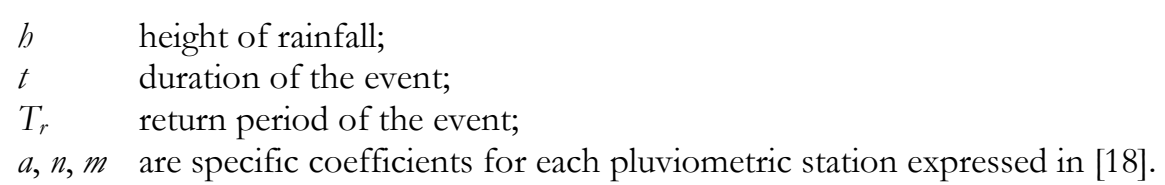

From (1), known the height of rainfall $b$ and the duration of the event $t$ the return period can be determined. 
The average pluviometric data of the stations in Bocca D’Arno, Santa Luce, Livorno Mareograph and Pisa Agraria give the return periods (Tab. 4).

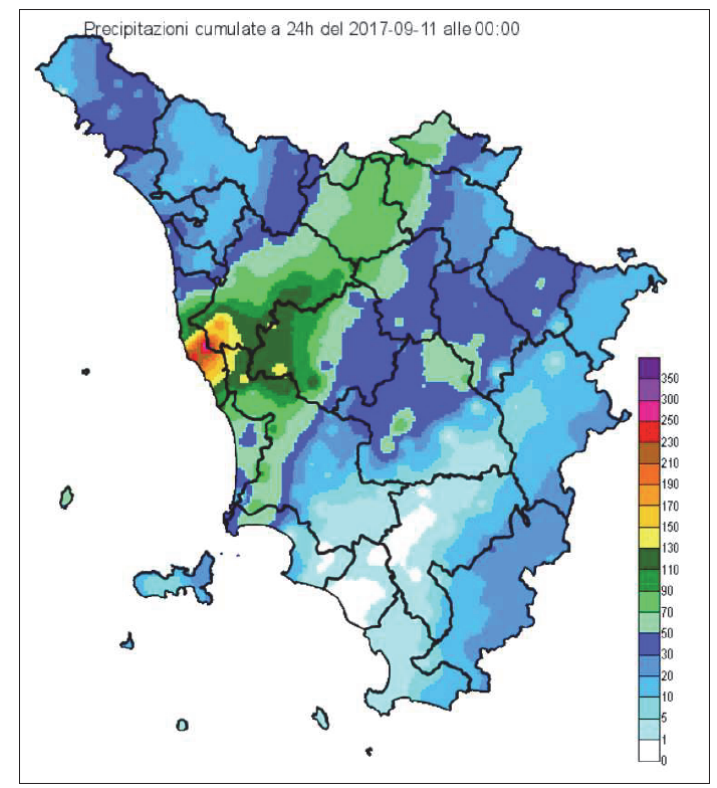

(a)

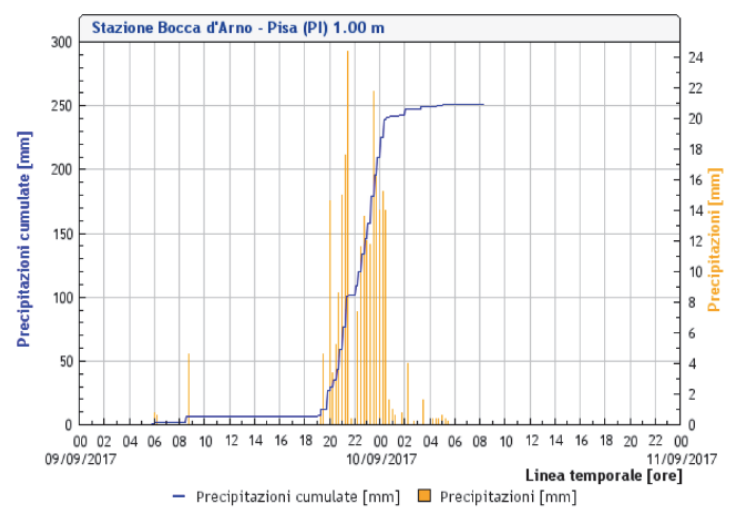

(b)

Figure 5: Rainfalls Scheme. Map of 24hours accumulated rainfalls - from the 0.00 of the 11th September 2017 (a); Station of Bocca d'Arno, Pisa - $1.00 \mathrm{~m}$ above the sea level (b).

\begin{tabular}{ccccc}
\hline Name of Station & \multicolumn{4}{c}{ Duration of rainfalls $(\mathrm{mm})$} \\
Quercianella & $15 \mathrm{~min}$ & 1 hour & 2 hours & 3 hours \\
Valle Benedetta & 42.4 & 121.8 & 188.6 & 206.2 \\
Santa Luce & 38.4 & 120.8 & 210.2 & 235.0 \\
Castellina Marittima & 23.0 & 66.4 & 98.2 & 105.8 \\
$\max$ & 40.2 & 89.6 & 109.6 & 122.2 \\
\hline
\end{tabular}

Table 3: Duration of rainfalls.

\begin{tabular}{cccccc}
\hline Longest duration & $1 / 4$ & 1 & 2 & 3 & hours \\
Return period & 16 & 756 & 2036 & 1240 & years \\
\hline
\end{tabular}

Table 4: Return period of the more severe events.

\begin{tabular}{|c|c|c|c|c|c|}
\hline Number & $\begin{array}{c}\text { Name of the } \\
\text { bridge }\end{array}$ & $\begin{array}{c}\text { Water } \\
\text { catchment } \\
{\left[\mathrm{km}^{2}\right]}\end{array}$ & $\begin{array}{c}\text { Hydraulic } \\
\text { pattern }[\mathrm{km}]\end{array}$ & Average slope & $\begin{array}{l}\text { Concentration } \\
\text { time }[\mathrm{h}]\end{array}$ \\
\hline 1 & Tre Ponti & 21.2 & 3.7 & 0.010 & 2.0 \\
\hline 2 & Chioma & 18.6 & 9.8 & 0.010 & 2.7 \\
\hline 3 & Limoncino & 4.9 & 8.6 & 0.019 & 1.7 \\
\hline
\end{tabular}

Table 5: Hydrological main data.

Estimated return periods associated to 1 and 3 hours rainfalls recorded during this event are much longer than 200 years (estimated numeric values of 500-1.000 years). It should be specified that the statistic data related to rainfalls in the [0, 200] year period do not allow their extrapolation, though providing a rather significant indicator. 
The watercourses causing bigger damages are Rio Maggiore, Rio Ardenza and Torrente Chioma. These streams are characterised by catching basins of a very reduced extension (included between 5 and $25 \mathrm{~km}^{2}$ ) and lengths included between 3 and $10 \mathrm{~km}$, showing corrivation periods shorter than three hours, as illustrated in Tab. 5.

The most remarkable event was the overflowing of Rio Maggiore. The filling of its final part took place in two stages and was concluded about 20 years ago. Upstream of the section where the Rio Maggiore is silted up there are four detention basins, recently created, mutually connected through a system of siphons (Fig. 6). The Rio Maggiore overflowing reached the first slab of some buildings, causing victims. According to surveys, the hydric height recorded in town equals about 50 $\mathrm{cm}$ in the filling mouth, up to a maximum of $4 \mathrm{~m}$ recorded in the lowest areas (Fig. 7).

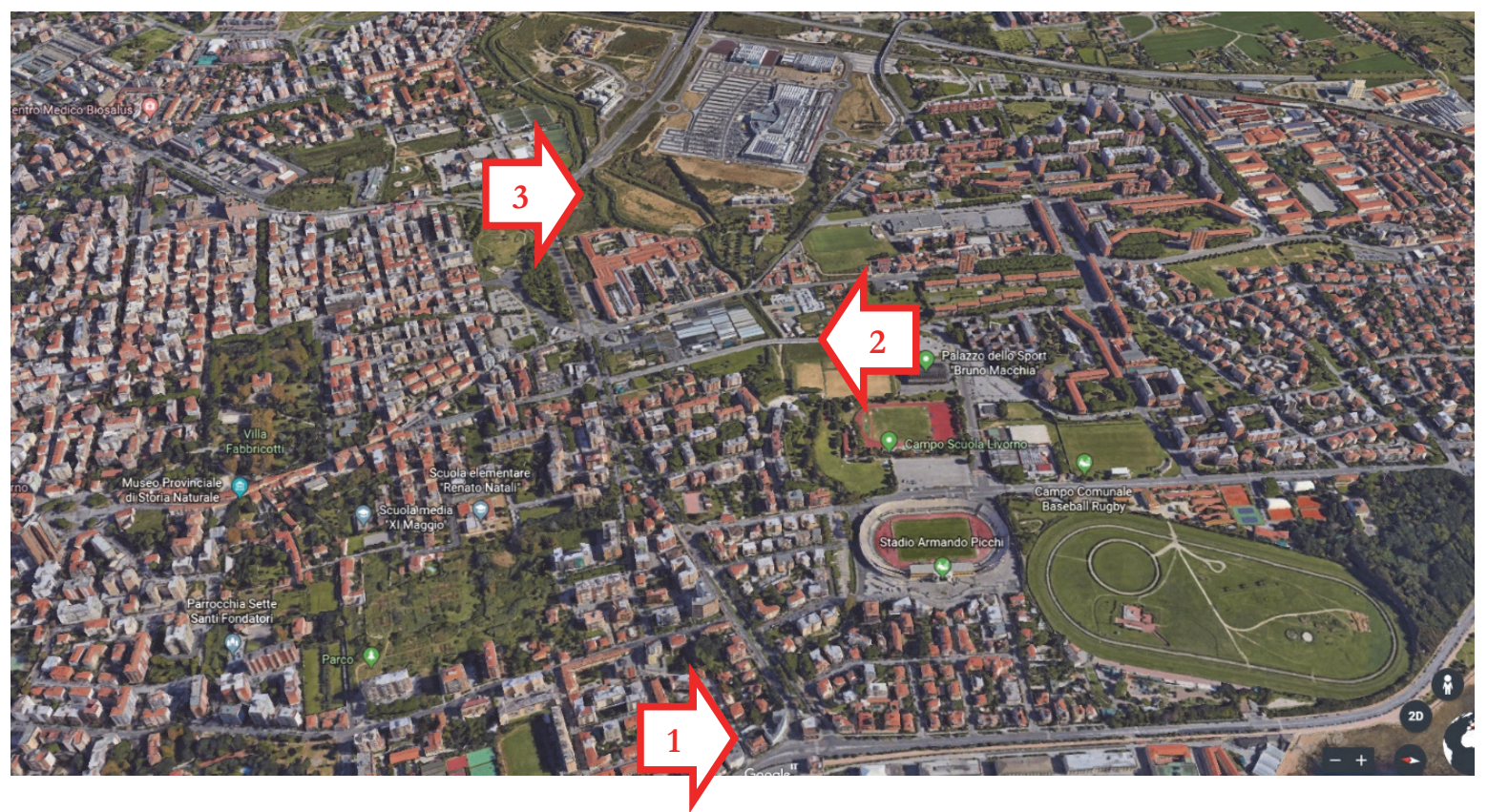

Figure 6: Top view of the area affected by the overflowing. (1) area of widest overflowing; (2) starting point where the Rio Maggiore is silted up; (3) one of the four detention basins.

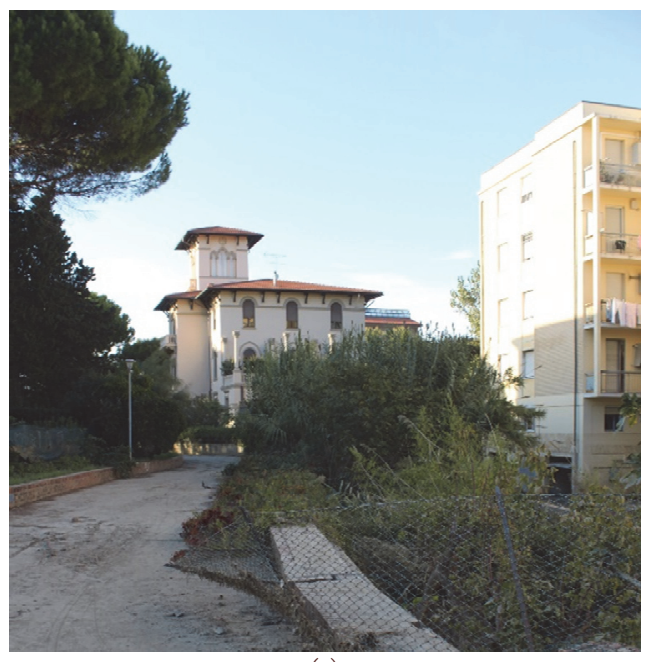

(a)

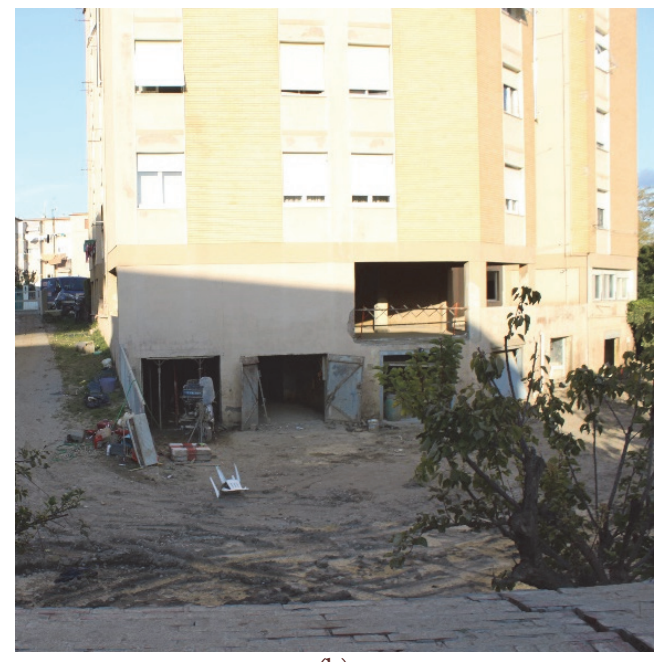

(b)

Figure 7: Buildings damaged by the flood, photo taken from an inner street near via Nazario Sauro. Building where the tragedy occurred, on the foreground a small wall overturned by the load of the flow; (a); other blocks of flats, the basement was totally flooded, the overflow reached the windows on the first ground (b). 


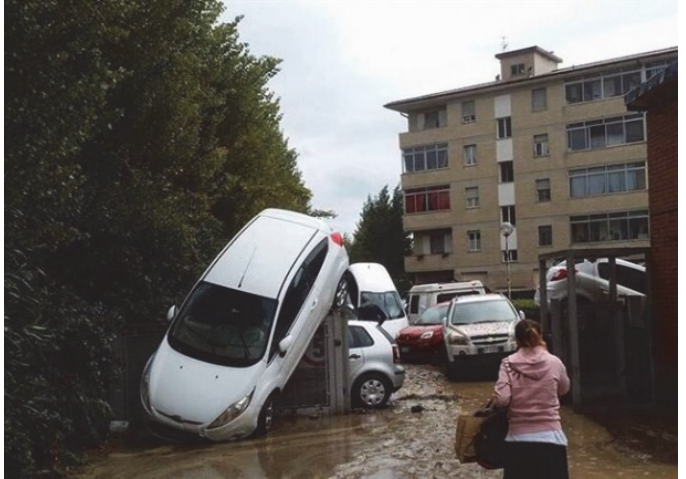

(a)

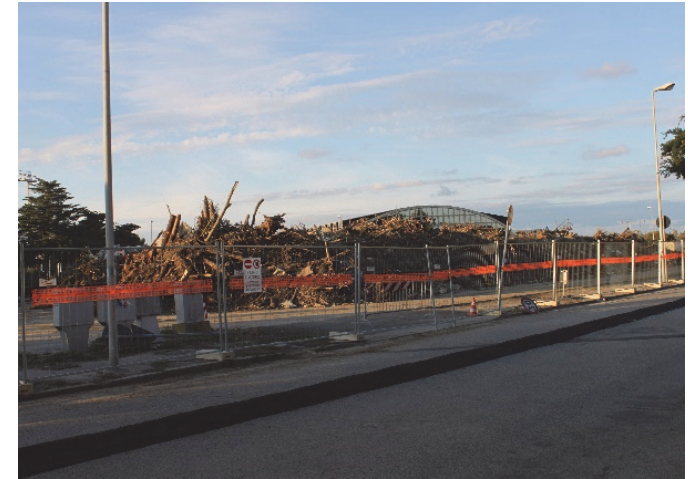

(b)

Figure 8: Cars damaged during the flood (a); waste carried by the flow, collected in a service area before being disposed (b).

Among the damages to infrastructures, two bridges totally collapsed while many others were damaged. The latter did not cause further victims since the event took place during the night and rainfalls, though in an urban environment, were so intense to inhibit the road access. In this work, three significant study cases will be analysed with reference to three recurring crisis mechanisms illustrated in [10].

These are: (1) the parapet collapse; (2) the dragging of decks; (3) the bridge abutments or the access ramps erosion. The hydraulic load on the deck in case of overflow can favour the latter. Surveys actually reported that the stream overflew the three bridges. References to the three study cases are reported as follows. Their position is identified in Fig. 9.

\begin{tabular}{|c|c|c|c|c|c|c|c|}
\hline $\mathrm{N}^{\circ}$ & Name & Technology & Type & River & Road & \multicolumn{2}{|c|}{ WGS 84 Coordinates } \\
\hline 1 & Tre Ponti & masonry & Arch & Ardenza & $\begin{array}{c}\text { Viale } \\
\text { Antignano }\end{array}$ & $43^{\circ} 30^{\prime} 42^{\prime \prime}$ & $10^{\circ} 19^{\prime} 06^{\prime \prime}$ \\
\hline 2 & Limoncino & r.c. & Beam & Maggiore & $\begin{array}{l}\text { Via delle } \\
\text { Valicelle }\end{array}$ & $43^{\circ} 31^{\prime} 39^{\prime \prime}$ & $10^{\circ} 22^{\prime} 31^{\prime \prime}$ \\
\hline 3 & Chioma & r.c & Beam & Chioma & $\begin{array}{c}\text { Via Mario } \\
\text { Puccini }\end{array}$ & $43^{\circ} 26^{\prime} 56^{\prime \prime}$ & $10^{\circ} 22^{\prime} 43^{\prime \prime}$ \\
\hline
\end{tabular}

Table 6: Study cases affected by the flood in Livorno.

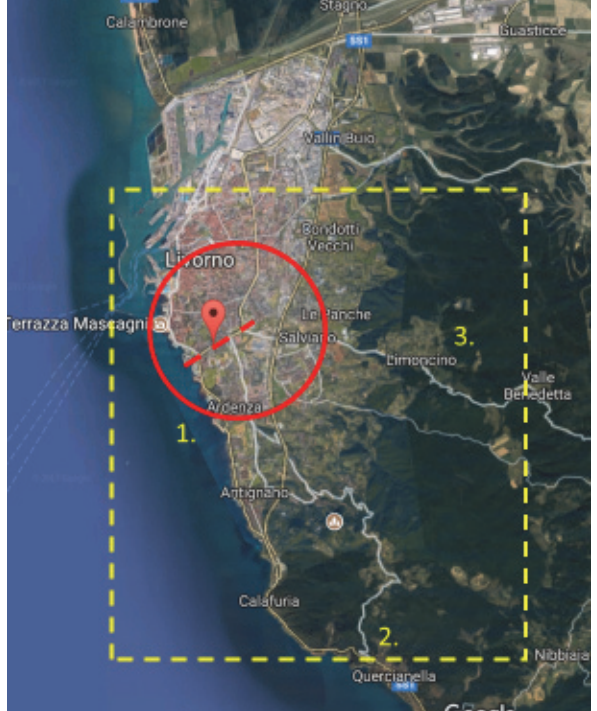

(a)

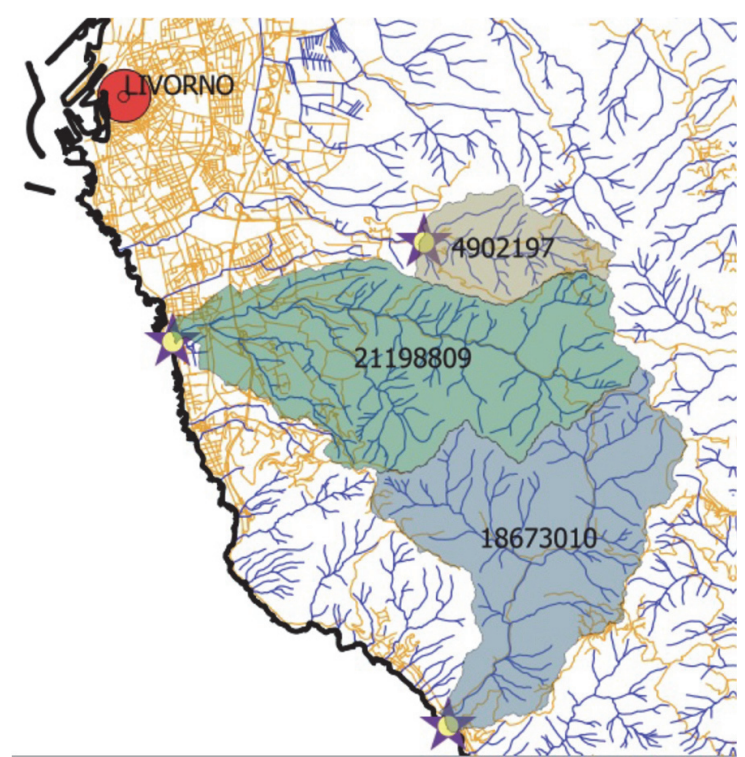

(b)

Figure 9: Identification of study cases. The bridge 1 is localized in the urban area while the bridges 2 and 3 in a suburban one. The circle highlights the flooded area where the Rio Maggiore overflew (a). Catching basins related to sections 1, 2 and 3 (b). 


\section{STUDY CASES}

\section{Case 1 - Tre Ponti}

1 he first study case is a stonework bridge. It takes its name from the original structure including three arches, later widened to 5 as shown in Fig. 10. The bridge is on the mouth of the Ardenza River. It presents a slight upstream widening of the outflow section, in discrete maintenance conditions and characterised by low and grassy vegetation. The latter allows the stream slow down, thus protecting infrastructures in case of flood.

The bridge is made of big ashlars. Instead, the parapet was realised with a mix and vertical holed bricks. The use of cinder blocks is not infrequent in the realization of parapets. Arches present spans of $6 \mathrm{~m}$ (for a total outflow of about $30 \mathrm{~m}$ ) and a rise of $3.5 \mathrm{~m}$. The widest outflow section (when the infrastructure operates under pressure) corresponds to $63 \mathrm{~m}^{2}$. A peak load equal to about $200 \mathrm{~m}^{3} / \mathrm{s}$ may be estimated as causing the collapse of a wide portion of the downstream parapet of the infrastructure.

The study of further similar cases showed that in overlap conditions the downstream parapet is more affected, while the gradual load on the upstream one is partially balanced as the hydraulic level increases.

The urgency provision for pedestrians' protection consisted in securing the site through concrete "new jersey" barriers (Fig. 11).

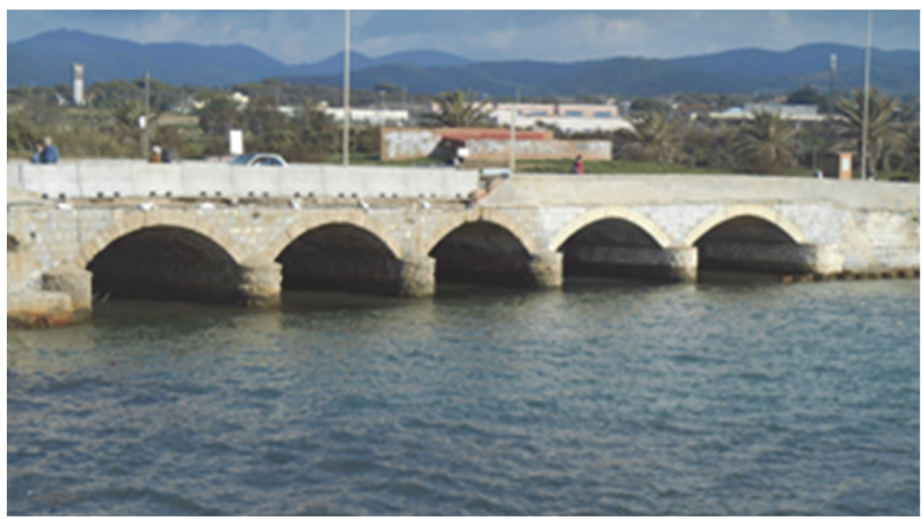

Figure 10: Bridge on the Ardenza river, view from the sea side.

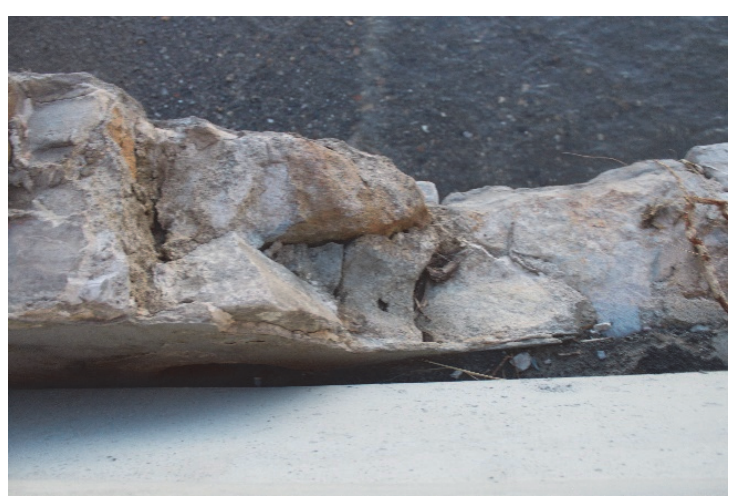

(a)

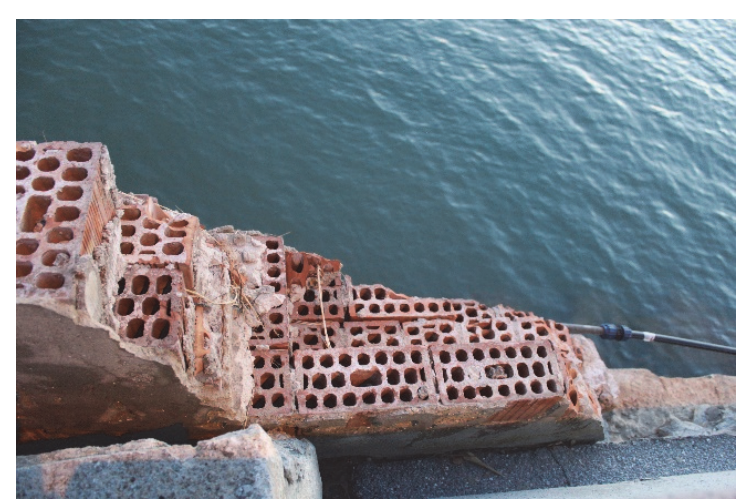

(b)

Figure 11: Residual portions of the parapet collapsed at "Tre Ponti".

\section{Case 2 - The Limoncino bridge}

The Limoncino bridge is located on the Rio Maggiore, in via delle Valicelle, a suburban area. The bridge stands between two cornering stretches, and is not frequently crossed. The lateral parapets are formed by a couple of guardrails of the Sidar type with a reinforced concrete frame.

The flood wave dug out the downstream abutment causing either the collapse or the cutting of the plants spread along the road network (Fig. 12 - a). The gabions protecting the banks in the upstream section were not affected (Fig. 12 - b), and this also due to a wider upstream section of outflow. The bridge was promptly reconstructed with steel bars and a reinforced 
concrete deck (Fig. 13 - a). The benefits of coating abutments with reinforced concrete walls were experimented in a section geometrically similar to the collapsed one, further downstream along the same watercourse. The section on the bridge, though insufficient to allow the free outflow of the stream, resisted to the flood thanks to concrete wing walls. (Fig. 13 - b).

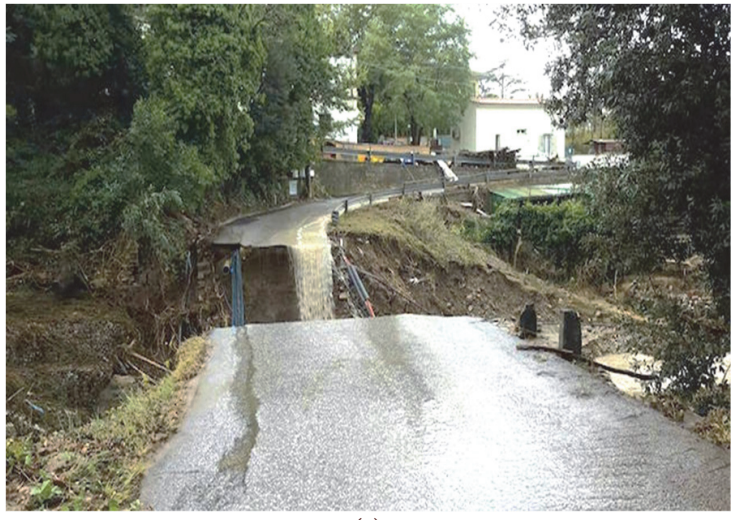

(a)

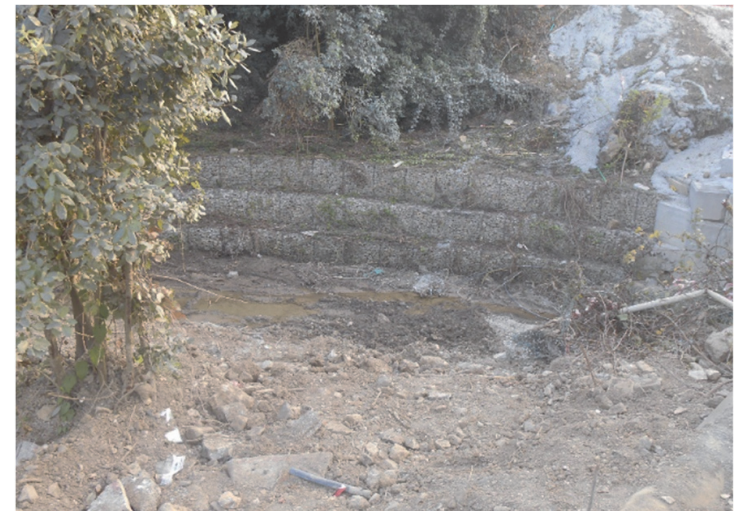

(b)

Figure 12: The collapsed bridge on the Limoncino (a). Section of the upstream riverbed protected by gabions (b).

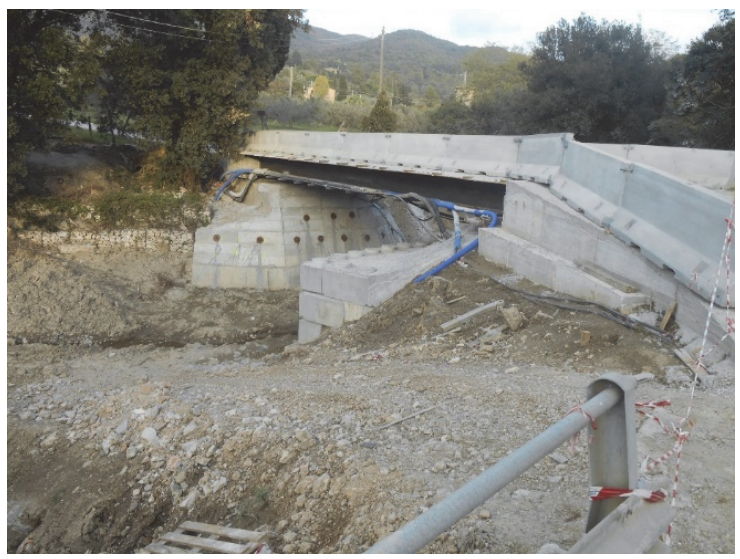

(a)

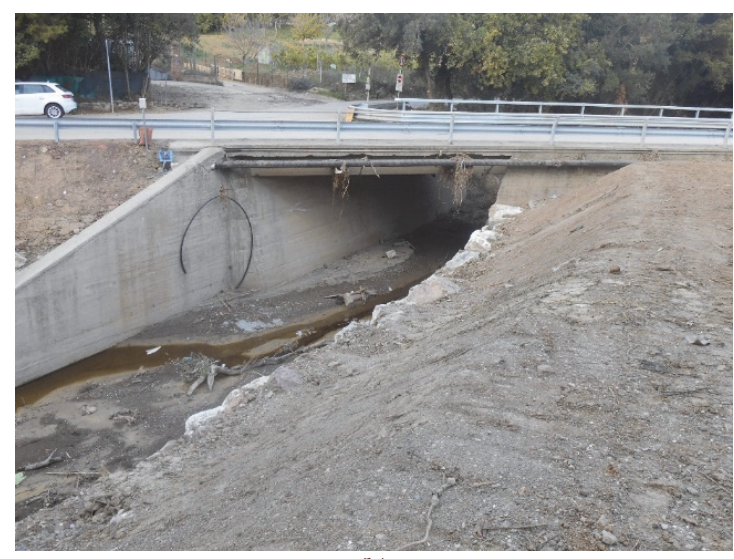

(b)

Figure 13: Reconstruction of the Limoncino bridge through steel beams and reinforced concrete abutments (a); further bridge on the Rio Maggiore showing overlap signs (b).

\section{Case 3 - Ponte Chioma}

This bridge stands on the river Chioma, near its outlet, inside a small touristic harbour. It is a bridge for vehicles, of the beam type, with an intermediate pier centrally positioned inside the riverbed. Parapets were realised with steel tubular profiles.

In this area four bridges stand very close to each other, of different types and building periods as represented in Fig. 14 (a). The outflow sections of these bridges arranged in a series are higher than the ones of the failed bridge.

The structure of the small harbour, with an outflow section widely extended to the sea and a good protection from the waves, allows favourable outflow conditions at the bridge (number 4 in Fig. 14 (a)). At 03:40 of 10 September 2017 (as proved by online videos) a free surface outflow was recorded at the level of the bridge intrados. An hour later the hydric level had reached the bridge extrados, making the infrastructure operate under pressure. At about 05.00 in the morning, after 30 minutes of this operating pressure, through the strongest hydraulic load, the infrastructure was crushed by the flow. The collapse occurred under a very strong hydraulic load, probably because the abutment on the right bank had been undermined, leading to the consequent collapse of the central pier. 


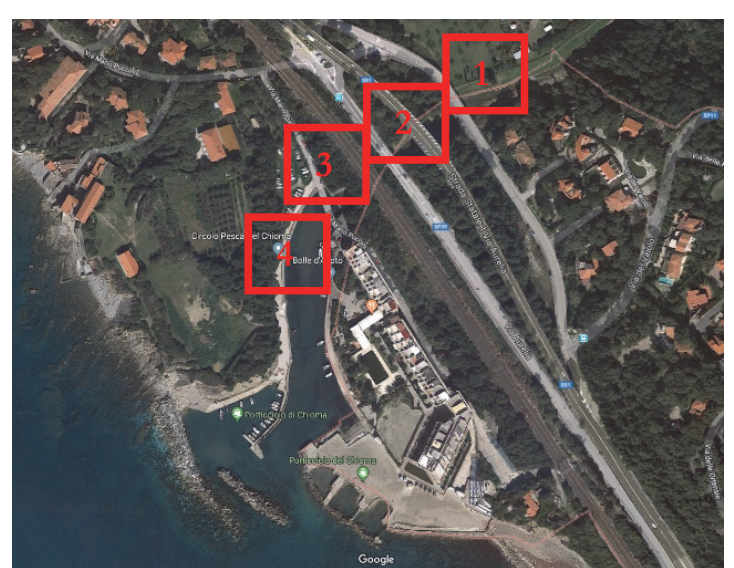

(a)

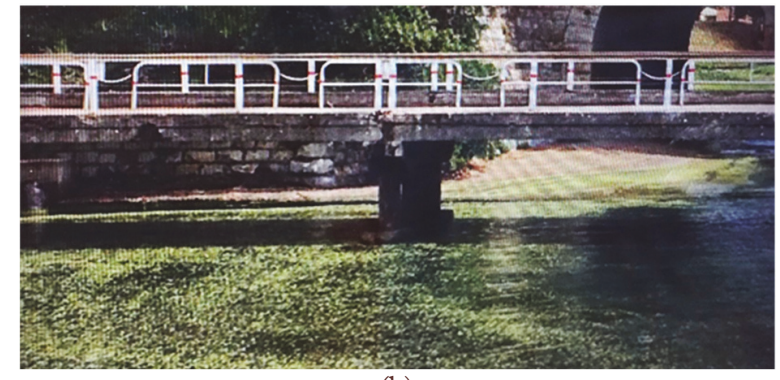

(b)

Figure 14: Top view of the Chioma small harbour (a) View of the small bridge with the intermediate pier (b).

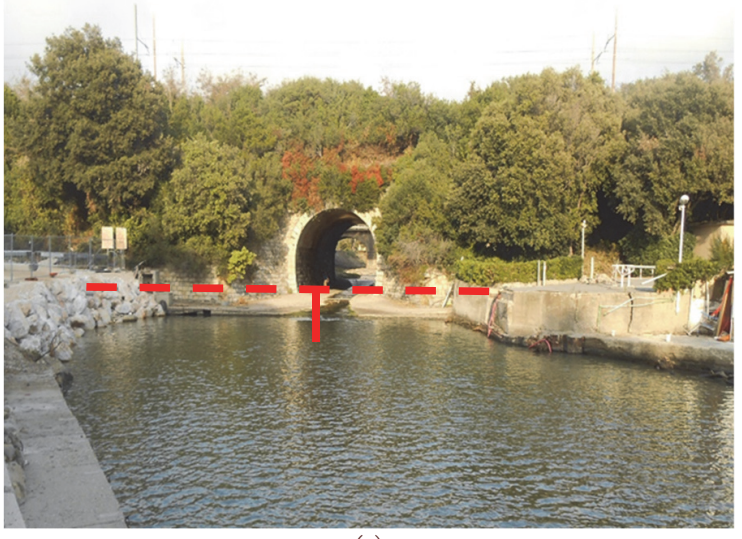

(a)

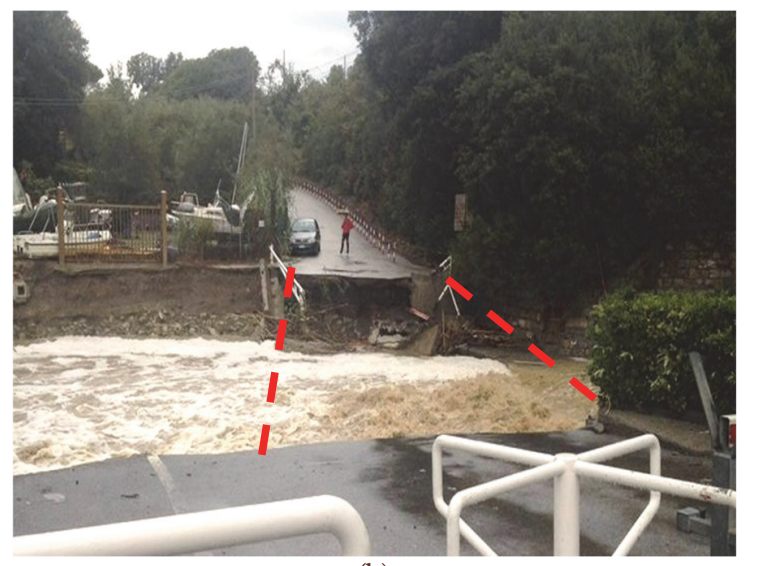

(b)

Figure 15: View from the Chioma small harbour (a) Bottom view of the harbour (b).

\section{Discussion}

\section{Limit states and capacity/ range}

T T 7 hile the crisis of wide span bridges fundamentally derives from structural reasons, the failure of a suitable maintenance and an inadequate concept of the structure or the pier erosion, for reduced span bridges the most frequent crisis is due to the interaction with the flow during floods [8]. Often the outflow span is insufficient for the loads [11] of the $\mathrm{Q}_{\mathrm{d}}$ project, leading to operate under pressure, i.e. to overlap infrastructures.

For this reason some limit flow rates, corresponding to three possible types of outflow, have been defined:

- FLS - QA the operating flow rate where the water level gets up to the intrados of the bridge;

- PLS - $\mathrm{Q}_{\text {в }}$ the operating flow under pressure, where the liquid level gets to the extrados of the frame;

- OLS - QC the overlap flow limit, where the water level overcomes the deck at a given height, dragging vehicles.

These flow rates can be determined starting from mere geometrical observations over the bridge spans, the width of the upstream and downstream sections, as well as the mean slope over the crossing and the mean longitudinal slope.

For each flow rate the corrivation method [19] allows calculating the corresponding height of rainfalls. As it is well known, this can be associated to a return period of the event through the Eqn. (1) [8].

In particular, for the considered cases, the limit flow rates acquire the values indicated in Tab. 7 . For each of them, given the data of the catchment basin referred to the related sections, the return periods determining them can be calculated. 
FLS

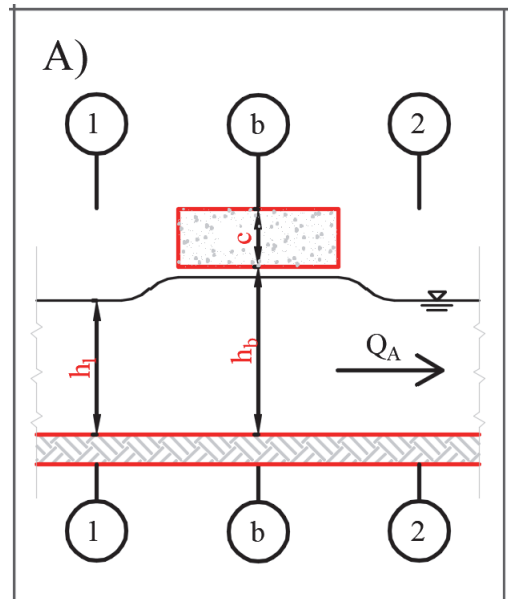

PLS

B)

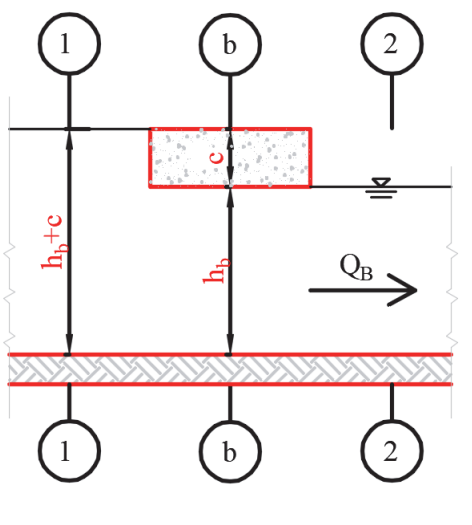

OLS

C)

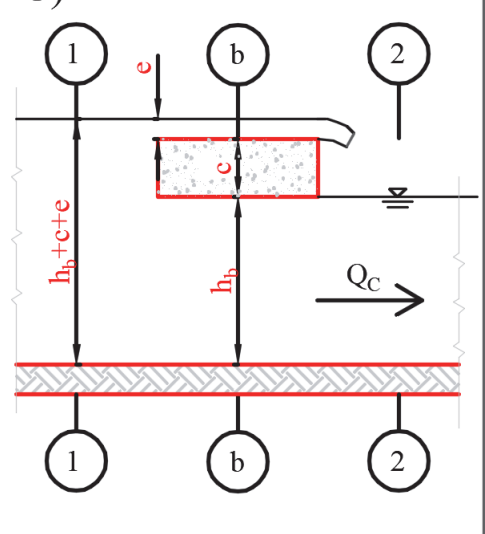

Figure 16: Flows condition, limit state A, B and C. Figs. 1 and 2 respectively indicate the upstream and the downstream section of the bridge.

\begin{tabular}{ccccc}
\hline $\mathrm{N}^{\circ}$ & Denomination & QA $_{\mathrm{A}}$ & $\mathrm{Q}_{\mathrm{B}}$ & QC \\
1 & Tre Ponti & 80 & PLS & OLS \\
2 & Chioma & 85 & 125 & 195 \\
3 & Limoncino & 340 & 465 & 160 \\
& & {$\left[\mathrm{~m}^{3} / \mathrm{s}\right]$} & {$\left[\mathrm{m}^{3} / \mathrm{s}\right]$} & {$\left[\mathrm{m}^{3} / \mathrm{s}\right]$} \\
\hline
\end{tabular}

Table 7: Limit flow rates for the three study cases examined.

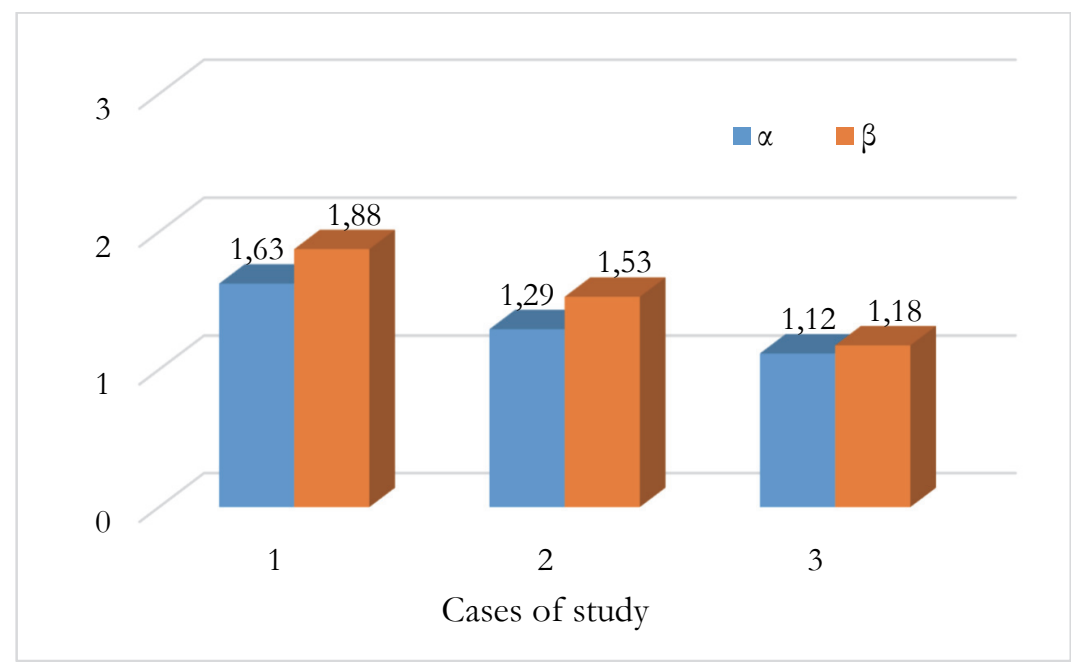

Figure 17: Coefficients $\alpha$ and $\beta$ for the three study case examined.

Normalizing the flow rates $\mathrm{Q}_{B}$ and $\mathrm{Q}_{C}$ according to the flow rate $\mathrm{Q}_{\mathrm{A}}$, the following coefficients are calculated. These are higher than the unit, being $\mathrm{Q}_{\mathrm{B}}$ and $\mathrm{Q}_{\mathrm{C}}$ always higher than $\mathrm{Q}_{\mathrm{A}}$ and represent the further outflow capacities that the bridge can have in unusual conditions. These are represented in the histogram of Fig. 17 for the three study cases examined. As it can be seen, the bridge 1 (Tab. 7) shows higher outflow capacity than the study cases 2 and 3. This does not prove the safety of the bridge, since in case of overlap the resistance to unusual and erosive actions has always to be considered [9]. 


$$
\begin{aligned}
& \alpha=\frac{Q_{B}}{Q_{A}} \\
& \beta=\frac{Q_{C}}{Q_{A}}
\end{aligned}
$$

\section{SUBMERGIBILITY AND RISK INDEXES.}

$\mathrm{T}$ he submergibility of an infrastructure is thus the first parameter to assess its level of exposure. As already recalled in the introduction, small bridges have problems due to the interaction with the flow. This does not include great infrastructures, since their planning follows a study of geological and hydrogeological feasibility providing for the realisation of a span through which the project $\mathrm{Q}_{\mathrm{d}}$ stream can outflow through proper free boards. Therefore, a risk index for submergibility of the infrastructure can be defined as follows [9].

$$
\begin{gathered}
I_{S, T}=\frac{T_{R B}}{T_{R d}} \\
I_{S, Q}=\frac{Q_{B}}{Q_{d}}
\end{gathered}
$$

i.e. between the return periods of the flow rate related to the B scenario and the return period of the project. The risk indexes can be referred both to return period (Eq. 4) than to flow rates (Eq. 5). This allows focusing attention on infrastructures vulnerable to the overlap risk. Risk indexes for several scenarios of collapse can be defined. This leads to a list of priorities for addressing more suitable interventions on the territory, either for emergences or prevention.

\section{CONCLUSIONS}

7 he flood in Livorno has highlighted the vulnerability of a highly anthropized territory. In this situation, a meteorological event with exceptional features caused serious damages and nine victims. Besides the flood in the south-central urban area, two small bridges collapsed and several others were damaged. The study cases have been described considering the elements that determined the crisis. A strategy was further presented for identifying the exposure of these infrastructures to submergibility.

If the bridge is submergible, but structurally suitable to resist to the exceptional actions in case of overlap, it is not the bridge to be protected but the users who might try to cross it during a flood. The crisis of parapets or other elements, though secondary ones (such as a tree collapsed in the access ramps areas) can expose the user to additional risks. In this case protecting the infrastructure through a system of early warning is suggested. Its activation is connected to the hydraulic level in correspondence of the bridge and the alert starts when the infrastructure operates under pressure. This system inhibits the vehicular flow on the infrastructure and sends an emergency signal to the monitors of the civil protection.

The assessment and the classification of bridges with a reduced span in our territory, the evaluation of their vulnerability aimed to identify proper strategies of intervention and possible protection through early warning systems represent a procedure to protect users of these bridges during floods. They are useful to mitigate the hydrogeological risk of reduced span bridges allowing a more suitable and cautious management of the territory.

\section{REFERENCES}

[1] Andreini, M., Giresini, L., De Falco, A., Puppio, M.L. and Sassu, M. (2015), Landslide phenomena after rainfalls in the recent case of Tellaro ( Italy), in 4th CEUP.

[2] Giresini, L., Puppio, M. L. and Sassu, M. (2016). Collapse of corrugated metal culvert in Northern Sardinia: analysis and numerical simulations, Spec. Issue Int. J. Forensic Eng., 3(1-2). 
[3] Houston, D., Werritty, A. and Bassett, D. (2011). Pluvial (rain-related) flooding in urban areas: the invisible hazard, November, pp. 96.

[4] Pahl-Wostl, C. (2007). Transitions towards adaptive management of water facing climate and global change, Water Resour. Manag., 21, pp. 49-62.

[5] Mirza, M. M. Q. (2003). Climate change and extreme weather events: Can developing countries adapt?, Clim. Policy, 3(3), pp. 233-248.

[6] Ryan, D., Ettema, R., Solan, B. and Hamill, G., (2015). Stability of Short-Span Bridges Subject to Overtopping during Floods: Case Studies from UK/Ireland and the USA, E-Proceedings 36th IAHR World Congr., pp. 1-11.

[7] Puppio, M. L., (2018) Safety assessment and structural reinforcement of reduced span bridges, University of Pisa.

[8] Elston, J. and Megginson S., (2015). Short Span Bridge Design Alternatives, in T.H.E. Conference, pp. 19.

[9] Harvey, B. (2012). Stiffness and damage in masonry bridges, Inst. Civ. Eng. - Bridg. Eng., 165(3), pp. $127-134$.

[10] Chandrasekaran, S. and Sandhya, B., (2016). Retrofit Optimization for Resilience Enhancement of Bridges under Multihazard Scenario, J. Struct. Eng., 142(8), pp. 1-12.

[11] Diaz, M. E. E., Moreno, F. N. and Mohammadi, J. (2009). Investigation of Common Causes of Bridge Collapse in Colombia, Pract. Period. Struct. Des. Constr., 14(4), pp. 194-200.

[12] Deng, D., Ph, D., Asce, D., Wang, W. and Yu, Y., (2016). State-of-the-Art Review on the Causes and Mechanisms of Bridge Collapse, Perform.Constr. Facil, 30(2), pp. 1-13.

[13] Xu, F. Y., Zhang, M. J., Wang, L. and Zhang, J. R. (2016). Recent Highway Bridge Collapses in China: Review and Discussion, J. Perform. Constr. Facil., 30(5), pp. 1-8.

[14] Choudhury, J. R. and Hasnat, A., (2015). Bridge collapses around the world : Causes and mechanisms, in IABSE-JSCE Joint Conference on Advances in Bridge Engineering-III, pp. 34.

[15] Novelli, S., (2017), Scenari di collasso di piccoli ponti per eventi climatici estremi nelle Colline Metallifere, Pisa.

[16] De Falco, A. and Galli, M. (2017). Territorial recognition of existing stream crossings to assess hydraulic and structural vulnerability, 'Infrastrutture Territ. esposte agli eventi Clim. esterni - Emergenze Territ. - PRA 2016', Pisa Univ. Press.

[17] Sassu, M., Giresini, L. and Puppio, M. L., (2017). Failure scenarios of small bridges in case of extreme rainstorms, Sustain. Resilient Infrastruct., 9689, pp. 1-9.

[18] Pagliara, S. (2011), Idraulica. TEP. 